Commemoration and the State:

Memory and Legitimacy in Vietnam,' special issue on 'Religion and Politics in Southeast Asia

Roszko, Edyta

Published in:

SOJOURN - Journal of Social Issues in Southeast Asia

DOI:

DOI.10.1355/sj25-1a

Publication date:

2010

Document version

Publisher's PDF, also known as Version of record

Citation for published version (APA):

Roszko, E. (2010). Commemoration and the State: Memory and Legitimacy in Vietnam,' special issue on

'Religion and Politics in Southeast Asia. SOJOURN - Journal of Social Issues in Southeast Asia, 25(1), 1-28. [5]. https://doi.org/DOI.10.1355/sj25-1a 


\title{
Articles
}

\section{Commemoration and the State: Memory and Legitimacy in Vietnam}

\author{
Edyta ROSZKO
}

\begin{abstract}
The commemorations of historical figures, both public and private, have become a powerful tool for politicians and historians in Vietnam to reconfigure the past, national heroes, and revolutionary martyrs. One of the state's commemorative projects is devoted to glorifying the Hoang Sa (Paracel) and Truong Sa (Spratly) soldiers, and preserving all temples and relicts related to their activities on Ly Son Island. This state project may be seen as a strategy to claim sovereignty in the face of competition from several nation states, including China, for control over the two archipelagos. Conversely, the Vietnamese state is also challenged by alternative accounts from the Ly Son people, who have introduced their own narratives. This essay analyses contestations over memory and the attempts of the Ly Son villagers to establish continuity with the past through their ancestors in order to demonstrate solidarity, patriotism, and their own prestige.
\end{abstract}

Keywords: ancestors, commemoration, ghosts, heroes, Ly Son, martyrs, religion, ritual, Vietnam

Commemorations sanitize the messy history lived by actors. They contribute to the continuous myth-making process that gives history its more definite shapes: they help to create, modify, or sanction the public meanings attached to historical events deemed worthy of mass celebration. As rituals that package history for public consumption, commemorations play the numbers game to create a past that seems both more real and more elementary (Trouillot 1995, pp. 655-66). 
In Vietnam, tens of thousands of soldiers who died fighting the French and Americans never received a proper burial or a grave with their name on it. The earth absorbed the flesh and blood of the combatants leaving only the bones - a thin thread connecting the dead with the living, a son with his parents, who hope that the bones belonged to their loved one. These soldiers and their martyrdom became most potent symbols of the official struggle over memory and legitimation of the war (see Malarney 2001). But the Vietnamese pantheon of war heroes comprises not only those who died recently resisting foreign aggression. National monuments, museums, and publications project a tradition of patriotic devotion onto the remote past. They commemorate events and long-standing traditions of "protecting ancestral land" dating back to the very origins of Vietnam. Heroic figures have emerged whenever the country has had to repulse a foe, and many of these figures have been incorporated into a national pantheon of heroes. Those who are not recognized by the state, however, have not necessarily been forgotten; rather, local officials, communities, and individuals often speak on their behalf. These groups engage in contestations over memory as they attempt to integrate their own narratives into the dominant official history and, thus, to turn their kin or fellow villagers - the "unknown dead", the "wandering souls" - into heroic and meritorious members of their locality.

Most generally, this paper is about rituals of commemorations, which, due to their capacity to shape national memory, constitute a powerful project of the representation of the past in modern Vietnam. Claims of continuity with the past, which distinguish commemoration from other ritual forms, places it in a special position among official symbolic images (Connerton 1999). Kertzer (1988) argues that contemporary political leaders are eager to use religious rituals and symbols to legitimize their power and engage people in institutionalized and emotional forms of action. In Vietnam, the commemoration of anniversaries of death have become a potent tool for politicians and historians to create the past, write narratives about national and revolutionary martyrs, and teach "proper" Vietnamese religious tradition. However, the self-consciousness 
of the state regarding its social power does not allow the majority of local commemorations to turn into national-level events (see Malarney 2007). Instead, the state keeps the number relatively small, while at the same time playing its role as patron of national/local tradition as well as of progress. The state controls and influences commemorations in various ways: through articles in academic journals, through provincial conferences by mapping out commemorative locations, and by designing the events themselves (Ho Tai 1995; Pelley 2002, p. 164). This process involves the selection and re-shaping of some narratives of the past, while fending off others, which remain silent.

In her inspiring essay, Hue Tam Ho Tai (1995) states that the Vietnamese state exercises complete control over the location, planning, and budgeting of commemorative projects. National monuments result not from confrontations between the visions of ordinary citizens and those of the state but from multi-vocality originating within the state itself. By contrast, I argue that this confrontation occurs at the local level, where commemorations of the past are contested. The local narratives can become open to negotiation, as they are products of multi-vocality initiated by various groups of Vietnamese: local officials, villagers, lineages, and individuals. As Kwon (2006; 2009) has demonstrated in his study of commemoration in Vietnam, the bereavement of families of civilians killed in military operations has not been acknowledged in national remembrance ceremonies, but it has produced different patterns in the domestic cult of ancestors. The perfection of the killing machinery of modern warfare, the destruction of bodies, and the infeasibility of a proper burial create all sorts of ghosts who have to be reconciled with the living through family commemorative rites. National history and heroism only have meaning for the local people when they are integrated with local history and the genealogical heritage of the community (Kwon 2006, p. 117). Thus, the aim of this paper is to explore commemorations and historical narratives from the perspective of the central state down to the notions of individuals. Instead of establishing a dichotomy between state and people, between the central and the local, however, 
I seek to demonstrate how these categories intersect with each other in everyday life (DiGregorio and Salemink 2007). This paper will contribute to the discussion of commemoration by showing the complexity of local contestations over memory and meaning (Evans 1998; Keyes 2002; Kwon 2006; Trouillot 1995).

One such commemorative venture of the state, which aims to preserve the primacy of those who died serving the country, is devoted to glorifying the Hoang Sa (Paracel) flotilla and preserving all temples and relics related to its activities on the offshore island of Ly Son. This small atoll is mentioned several times in various historical documents due to its connection with the Paracel (Hoang Sa) and Spratly (Truong Sa) islands (Han Nguyen 1975; Lang Ho 1975). The state project seeks to prove that the Vietnamese feudal monarchies had occupied the Paracel and Spratly archipelagos and exercised sovereignty over them for centuries. Moreover, the competition between several nation states, including China, for control over the two archipelagos links these local commemorations to international affairs; but the Vietnamese state has to face not only international but also local negotiations, since the Ly Son people introduce their own accounts of this emotionally charged issue.

Besides the dispute over sovereignty, these negotiations are inscribed in the Vietnamese discourse on culture and religion. This discourse, prompted by the state, concerns ancestor worship, which is one of those religious practices that has received state recognition as "a national religious tradition". According to the definition of Dang Nghiem Van (1998, p. 246), ancestor worship is "the veneration of those passed away who deserve credit for the generation and nurture of their descendants ... or who have achieved merit in service to their commune or country". Ancestor worship, he observes, is a long-standing religious tradition of the Vietnamese people, which is deeply rooted in their consciousness, since it represents national custom and is "imbued with a sense of duty" (p. 247). Kwon notes that "the traditional religious institution became the technology of national integration. Imagining the nation-state became a matter of thinking about dead war heroes within the familiar system of 
ancestor worship". In this light, the traditional cult of ancestor worship has recurred as a "hero-centred political culture", since the state's focus is on the exemplary service of the ancestors, rather than the peaceful afterlife (2006, p. 104). Nevertheless, the Vietnamese people take a more egalitarian approach to the dead: the spirits of all ancestors regardless of their merit or contribution and even the ghosts of strangers all deserve to be acknowledged. I will elaborate this statement by showing how both the categories of ancestors and ghosts are included in the process of recovering the memory of soldiers of the Hoang Sa navy on Ly Son Island.

Drawing on ethnographic material gathered on the offshore island of Ly Son, I refer to commemorations as I examine the case of Anh, ${ }^{1}$ who attempted to include the ancestress of his kin group - a "potential ghost roaming through the village" - into the provincial pantheon of Hoang Sa's heroes. Personal narratives are confronted with official history when authors try to "insert" their own versions of events into the structure of the dominant discourse and give them their own sense (Connerton 1999, p. 19). As a consequence, the recognition and commemoration of the dead highlight different aspects and have diverse meanings for the state and people. The state seeks to promote its own ideological aims, such as legitimizing the war, showing its continuity with previous heroes and dynasties in its resistance against foreign invasion, and building a "strong and happy country". For the common people, however, local, lineage, or individual recognition, rather than national goals, are most important. Nonetheless, heroism has become an essential element of local narratives, as the Vietnamese seek to restore their kin bonds through patriotism. This process is congruent with phenomena that anthropologists have observed in recent years in Northern Vietnam (see DiGregorio 2007; Endres 2001; Endres 2002; Malarney 2002).

\section{Culture, Religion, and Scholarly Discourse}

Vietnamese traditional culture is subject to constant scrutiny by politicians and intellectuals. In revolutionary times, they put the 
blame for colonial hegemony and economic backwardness on certain aspects of the culture, such as hierarchy, waste, and irrationality, which they believed were not appropriate in a modern state and should be eradicated (Endres 2002). In 1943, the Vietnamese Communist Party, in its "Theses on Vietnamese Culture", introduced three principles: nationalization, popularization, and scientism (dan toc hoa, dai chung hoa, khoa hoc hoa) as the "guiding concepts for the project of building a 'new culture' and a 'new life"' (p. 2). As Endres shows, nationalization was understood as a defence against hostile forces and, therefore, occupied a particular place in the ideological and academic discourse. It was believed that a systematic selection of "proper" aspects of Vietnamese tradition and customs would put an end to "corrupt and feudal practice". In light of such rhetoric, village festivals, life cycle rituals, and places of worship - the spaces that sustained old power and prestige - became targets of the state's campaign against superstitions. As noted by Anagnost (1994, p. 222), the state framed the local landscape in "its own totalizing order". In Northern Vietnam, from the 1950s to the late 1980s, sacred spaces, which, it was believed, sustained unequal relationships and wasted village resources, were converted into granaries, storehouses, and schools, while the monks and nuns were forced to cast off their robes and return to secular life. Spirit medium rituals were banned and ritual professionals were controlled by local authorities (Luong Van Hy 1992; Malarney 2002). After 1975, this process spread across the southern parts of Vietnam as well and lasted until 1986, when the state relaxed its enforcement of anti-superstition laws (see Taylor 2004, p. 39).

However, the marginalization or even desecration of religious space hardly led to a break with religious traditions (Malarney 2002; Poon 2004, 2008; Yang 1967, p. 366). In the late 1980s, along with the gradual opening of Vietnam to the international community, traditional religious practices experienced a strong revival, and acute cultural and social changes in Vietnam were brought about by reforms called doi moi (renovation). "Culture" and "tradition" now took an important place in the process of socio-economic change. According 
to the Communist Party, cultural campaigns, as crucial components of the new nation-building process, should help to "prevent and drive back negative practices, social evils, and harmful cultural products". As in other Asian countries such as Korea, Japan, and China, national folk tradition in Vietnam was cast in opposition to "Western things" (Kendall 2001; Endres 2002). The state has begun to promote a new rhetoric of harmony between ethical religious values and the ideology of the socialist system. As a result, religion now supplements economic and social life, providing moral and cultural reinforcement for the state's social projects.

A gradual change of socialist state attitudes towards culture was accompanied by scholarly debates reacting to the revival of religious traditions. Special attention was given to the "national cultural identity" (ban sac van hoa) of Vietnam, which was seen as the "essence" of the nation. Scholars produced articles describing at length how "national cultural identity" contributed to the "skills and spirit", "vital power", and "experience" of the Vietnamese nation, which, in turn, made it possible for Vietnam to emerge triumphantly from the trials of history.

The sense of being a patriot (yeu nuoc) and patriotism (chu nghia yeu nuoc) were acknowledged as the most important characteristics of national cultural identity. Kendall (2001) reports that in the 1980s a new Korean middle class of intellectuals believed that the real essence of a people was in their folk traditions. Similarly, Vietnamese academics saw a "will to build and preserve the country" in traditional society, especially in popular culture (see Ngo Duc Thinh 2001). Tutelary spirits and craft ancestors, who, during the campaigns against superstitions, had been erased from village ritual landscapes, have returned in all their glory as historical characters having merit for the nation. Family and lineage rituals are seen as the cement of village communal spirit and as serving to educate the people by teaching basic concepts of morality. However, as Siu (1989) rightly points out in the case of China, the ritual revitalization represents the recycling of cultural fragments in a rural society, rather than the resurgence of traditional practices. These rituals are today 
reconstructed by diverse groups of actors and mean different things to different people (ibid.).

\section{Canonization of Heroes and "Certified" Memory}

In opening up public space for religion, the socialist state neither admits limitations to its power nor resigns control over religious practices. Although the state no longer plays the strong ideological role in people's lives that it did before doi moi, it still tries to standardize religious practices. Among the most important means to this end are attempts to incorporate traditional aspects of ancestor worship into "a national religion" and policies of preserving historical sites. Local state agents are encouraged to apply for official recognition of commemorative sites for which they can prove an artistic and historic value or the historical or cultural character of the residing deity (Endres 2001, 2002, p. 6). At the same time, villagers who want to reclaim their sacred spaces and to confer institutional significance on them try to obtain a "Certification of a Ranked Historical and Cultural Relic" (cong nhan di tich lich su van hoa). Such a certificate provides state recognition for the temple, thus enabling people to worship their divinities in any way they wish; and it is also a source of personal consolation and communal pride.

The modern practice of the socialist state granting certificates to heroes, divinities, and temples with historical and national importance has a long tradition in Vietnam, dating back to imperial times (see Boudarel 1991; DiGregorio and Salemink 2007; Do Thien 2003; Wolters 1988). Like the imperial court, the socialist state seeks to increase its legitimacy through the careful selection and canonization of those historic figures who demonstrated moral and patriotic values and heroic resistance against foreign invaders (see Malarney 2007, p. 529; Pelley 2002, p. 177-89; Pham Quynh Phuong 2009).

\section{Commemoration of the Hoang Sa Flotilla}

Let us now take a closer look at one example of such canonization, which took place in the coastal province of Quang Ngai in Central 
Vietnam, in order to demonstrate how national negotiations over memory and meaning are intermingled with international and local ones. However, before I turn to the state's project of preserving relicts of the Hoang Sa expedition, it is important to convey a sense of the local ambiguities that shaped the history of Quang Ngai province.

In the eighteenth century, the province was the location of a civil war known as the Tay Son uprising. Furthermore, during the resistance war against the French the province was a stronghold of the Viet Minh. For the period of the Vietnam War, like other provinces of Central Vietnam, Quang Ngai, due to its location in the vicinity of the demilitarized zone, suffered exceptional destruction (see Kwon 2006).

From the seventeenth to the nineteenth century, Hoang Sa (Paracel) and Truong Sa (Spratly) flotillas played an important role in the exploitation of the South China Sea under the Vietnamese feudal state of the Nguyen lords (1558-1777), the Tay Son (1778-1802), and the Nguyen dynasty (1802-1945). ${ }^{2}$ The flotillas' responsibilities included collecting precious sea products and goods from wrecked ships in the area of the Paracel and Spratly archipelagos. ${ }^{3}$ Vietnamese scholars consider these operations to provide evidence of Vietnam's long-standing sovereignty over the islands, despite China's claims to the contrary. ${ }^{4}$ During the French colonial rule in Vietnam, China began to show interest in these uninhabited islands and to assert claims over them. With time, the conflict over control of the archipelagos escalated and became widely known to the international community. After the Chinese invasion of the Paracel islands in 1974, the Saigon administration persisted in its belief that the islands were Vietnamese territory. After reunification, the socialist government continued to claim Vietnamese sovereignty over the two archipelagos. ${ }^{5}$ At the present time, the Paracel and Spratly Islands remain controversial issues between China and Vietnam, as the two countries both claim them as their own. In addition, the Philippines, Malaysia, Taiwan, and Brunei all make partial claims as well. The maritime borders between China, Vietnam, and other countries have 
never been fixed, and, by law, all Vietnamese official maps include the Paracel and Spratly Islands.

The Paracel Islands lie to the east of the small Ly Son atoll, formerly named $\mathrm{Cu}$ Lao Re. Ly Son is located twenty-five kilometres offshore from Quang Ngai province in central Vietnam and about 400 kilometres from the Paracel Islands. At present, Ly Son has an area of ten square kilometres with 20,000 citizens living in three communities: An Hai, An Vinh, and An Binh. Seventy per cent of the islanders practice farming, not fishing. Moreover, Ly Son Island, which remained unscathed during the Indochina War and Vietnam War, is a storehouse of data on the settlement and development of the Viet people in central Vietnam. It is also a potential attraction for future tourism.

In the early 1990s, the socialist state turned its attention towards Ly Son Island as a source of information about the soldiers of the Hoang Sa and Truong Sa. The atoll's proximity to the archipelago is noted several times in eighteenth century historical documents: it took three or four days for the Hoang Sa navy from Sa Ky port to reach the Paracel (Le Quy Don 1972, p. 203; see Han Nguyen 1975, p. 140). The eighteenth century historian, Le Quy Don (1972, p. 210), reported that the Hoang Sa flotilla consisted of villagers recruited from Ly Son Island (see also Nguyen Dang Vu 2001; Tran The Duc and Nguyen Van Huong 1975). Many of them died at sea, their bodies never to be returned to their relatives. Some of their names, however, were preserved in place names: small islets of the Paracel archipelago bear the names of Captains Pham Quang Anh and Pham Huu Nhat, who stood out from others because of their skills and expertise (Son Hong Duc 1975). In 1994 and in 1995, a group of scholars from the Faculty of History of Hanoi National University visited Ly Son several times and inquired about the history of the island and the Hoang Sa navy. In the context of a large-scale project for the preservation of "cultural heritage", these scholars visited a number of families, collecting various documents and family records, and recording oral traditions. The results of the investigations were published by Nguyen Quang Ngoc and Vu Van Quan (1998), 
who wrote about the role and activities of the Hoang Sa navy in an article entitled "Sources on the Origin, Tasks and Activities of the Paracel Army". At the beginning of the publication, they praise the feudal monarchs for their deep consciousness of the significance of the Eastern Sea (the Vietnamese term for the South China Sea) and their efforts to protect and extend their possession over the whole region of the archipelagos. The Hoang Sa navy, which was responsible for patrolling, controlling, protecting, and exploring the South China Sea, partly in the Paracel and Spratly regions, became an example of how Vietnamese command was exercised from the seventeenth to the middle of the eighteenth century and, thus, serves to legitimate claims on these islands.

Therefore, it is no surprise that, on 3 August 2001, the Vietnamese prime minister issued a directive on establishing and reconstructing a zone with historical sites ( $k h u$ di tich lich su) of the Hoang Sa and Truong Sa. The purpose was to preserve all places with historical significance for the heritage of the forefathers and of Vietnam's sovereignty over the Paracel and Spratly archipelagos (Nguyen Dang Vu 2001). In early October of the same year, the representatives of the National Border Defence Committee and of the Ministry of Culture and Information visited the Ly Son district in order to "explore the current situation of all places of historical value" connected with flotillas of the two archipelagos. In the days that followed, a conference was organized in close collaboration with local authorities, including members of the Quang Ngai People's Committee, local researchers, and scholars from the Hanoi National University. Although the anniversary celebration of Hoang Sa and Truong Sa soldiers was included in commemorative projects, the state preferred to maintain a low profile for these ceremonies, as the whole issue of Paracel and Spratly was highly political.

The scientific and official interest in the historical past of the South China Sea region did not go unnoticed in the littoral community of Ly Son. The then-head of the Quang Ngai Journalist's Association, along with local historians, archeologists, and authorities, became officially and personally engaged in the process of recovering historical 
materials. They encouraged their kin and fellow villagers to collect all existing written documents that might have historical value and contribute to the reconstruction of patriotic traditions on the island. Many recent ethnographic studies report that, following the relaxation in cultural policy and the revival of traditional religious practices in Vietnam, it became common for lineage representatives to invent or reinterpret life stories of spirits and to hire scholars to help prepare petitions (see DiGregorio 2007; Endres 2001; Ho Tai and Le Hong Ly 2008). In the spirit of this "commemorative fever" (Ho Tai 2001, p. 1), various lineages in Ly Son began to compete with each other in demonstrating the meritorious and patriotic services of their ancestors and obtaining the "Certification of Designation of a Historical and Cultural Relic". Some of them even employed scholars to write letters to the provincial Office of Culture in support of claims regarding the cultural and historical value of their legacy. The main competition took place between two lineages, Vo and Pham. Whereas the first had the support of their kin - a provincial official devoted to cultural studies - the latter established good connections with wellknown historians and local authorities through the person of the lineage's representative, $\mathrm{Mr}$ Anh. Both lineages trace their origin to the first families of migrants who today are venerated in the village communal house as "pioneers" or as "those who first broke the land" (tien hien). ${ }^{6}$

The two lineages, both from An Vinh village, were proud that their family annals (gia pha), which had been preserved and handed down for centuries, were to be taken by scholars to Hanoi and sent to the Institute of Sino-Vietnamese Studies for translation. The originals, containing descriptions of local events, names, and information about the life of respected ancestors, were later returned to the owners; copies were made and kept in the library of the institute.

The growing attention of intellectuals and officials helped the people of Ly Son to restore their sacred places. In 1997, the An Vinh villagers put all their efforts into collecting money and rebuilding the temple that the ancestor of the Vo lineage had originally built for the village. The villagers installed altars in the temple devoted 
to worshipping the founder of the temple, the tutelary spirit, the spirit of the soil, the spirit of Bach Ma (White Horse), and to the Hoang Sa officer, Vo Van Khiet — just to name a few. To obtain the "Certification of Designation of a Historical and Cultural Relic" one has to prove the artistic and historical value of a place or the merit of the ancestor worshipped (Endres 2001, p. 88). Vo Van Khiet seemed perfect for fulfilling all official requirements. The Vo lineage had all necessary documents to prove his meritorious service for the village as well as for the country. In the Vo family record, dated 1803, we can read that due to Vo Van Khiet's virtues he was appointed head of the dinh (communal house) by the villagers of An Vinh (in Nguyen Quang Ngoc and Vu Van Quan 1998). He was described as a straightforward, honest, diligent, and knowledgeable person. The lineage, together with villagers and with the help of their kin and other local authorities from Quang Ngai, prepared the necessary petition. In 2001, the temple was listed in the official report of the Provincial Office of Culture along with other monuments for the commemoration of the Hoang Sa flotilla. The document lists Vo Van Khiet's temple as a historical site of the Paracel (UBND Tinh Quang Ngai and So van hoa Thong Tin 2001)

At the same time, the Pham lineage began their efforts to reaffirm the meritorious service of their female ancestor, Lady Jambose, and her historical value. Although they had not been backed by the villagers, as in case of the Vo kin group, in 2003, the Pham lineage received official permission and support from local authorities of the district People's Committee to apply for recognition of Lady Jambose's temple as a historical site. A year later, the members of the lineage unexpectedly came across additional documents preserved in their ancestral house when collecting materials for the Quang Ngai Museum. The newly discovered credentials included a genealogy (pho he), the family record, a charter (sac phong), and altar tablets that not only shed new light on Lady Jambose herself but also on one of the lineage's ancestors - a captain of the Hoang Sa flotilla — Pham Huu Nhat, after whom one of the islets of the Paracel archipelago was named. With the help of the head of the Quang Ngai Journalist's 
Association, archaeologists from the local museum, historians, and authorities from the province and district, celebrations were held in March 2005 for the unveiling of a commemorative plaque in honour of Pham Huu Nhat, who was then officially recognized as a respected ancestor of the Pham lineage and a soldier of the Hoang Sa navy. However, the struggle for the certificate was not concluded yet. The lineage continued to look for the support of well-known historians and journalists and even of Da Nang television. The lineage, having such unquestioning supporters, hoped for quick success.

Whereas there was no contestation concerning the heroism of Pham Huu Nhat, the attempt of the Pham lineage to recognize their second ancestor, Lady Jambose, met with strong opposition from the members of the Vo lineage, who felt that the Pham wanted to elevate their lineage over others through the deification and official recognition of their ancestress. By acknowledging Vo Van Khiet as a collective ancestor of the whole village, Vo lineage members stressed their self-effacement, which contrasted, they believed, with the more individualistic aspirations of the Pham lineage, which sought only its own glory.

\section{A Local Heroine or Ghostly Spirit?}

In Vietnamese belief and custom, as among the Chinese (see Wolf 1974), ancestors of one kin group can be dangerous to members of other kin groups, who view them simply as "ghosts". Other potentially dangerous ghosts, who may threaten not only non-kinsmen but their own family members as well, include those whose lives were interrupted unexpectedly and brutally. They cause a particularly serious problem if their death occurred in an unfamiliar place, out of "the domain of domestic security" and of the ancestor altar (Kwon 2009, p. 89). The soldiers of the Hoang Sa navy whose bodies sank into the deep water of the South China Sea could be included in such a category. For fear of dying away from home, the Hoang Sa soldiers going to sea prepared a straw mat, rattan rope, bamboo poles, and a small wooden tablet with information about their 
name, age, native village, and designation of their unit. In case of one's death, the comrades of the dead soldier wrapped his body in the mat and attached it to the poles and then lowered it from the boat into the waters in the hope that some of the living would find the beached corpse and give it a proper burial. Most of the time, however, the bodies of soldiers never returned to their kin. The Ly Son people, who did not want to leave their loved ones unburied, prepared fitting interments and fake graves in order to console the "wandering souls" of those who died tragic deaths (Nguyen Quang Ngoc and Vu Van Quan 1998, p. 14).

Finally, a potentially dangerous category of ghosts includes the spirits of virgin girls who died a violent and untimely death. They are thought to be pervaded by memories, unfulfilled desires, and unrequited lust (Taylor 2004, p. 201), which makes them want to remain among the living. They pose a problem in terms of ancestor worship since they have no descendants to venerate them. If forgotten, they can turn into angry ghosts and harm the living. It is believed that they are especially envious of motherhood and therefore can cause the death of children in their kin group or even in the whole village. In turn, worshipped with care, they may also earn reputations for responsiveness and efficacy. Without heeding whether the wishes and requests of the living are good or bad, these spirits grant all of them in return for the satisfaction of their needs (ibid.). Thus, the closest relatives of the dead usually set a separate altar outside the house or even build a small shrine where they commemorate and honour these women by burning incense and offering food in order to achieve happiness and peaceful coexistence.

In Ly Son, the Pham lineage tried to obtain recognition not only for its ancestor Pham Huu Nhat who died violently — the soldier of the Hoang Sa flotilla, whom the Vietnamese state ultimately acknowledged — but also for its ancestress Lady Jambose. I learned that she was one of a few cases of young women in Ly Son who died accidentally. Although I found that the individual Pham family members had different versions of her story, one of them especially riveted my attention: the version that Anh - the representative of 
the Pham Lineage Association - tells, based on recently discovered annals. The annals, originally written in Chinese characters, are dated to the seventeenth century. The transcribed document dated 1900 was only translated into vernacular Vietnamese by a local specialist in the Sino-Vietnamese language (Han Nom) in 2004. In the same year the document was authorized by an official of the Ly Son People's Committee. A lacquered box containing the sacred annals was displayed on an ancestor altar of the lineage temple and kept away from unauthorized persons. However, Anh prepared several paper copies of a new modernized version that he showed whenever someone demonstrated interest. According to these annals, which were unexpectedly discovered by Anh in the Pham's ancestor halls in 2004, Lady Jambose was a second-generation descendant of the first migrants and founders of the village who settled on the island in the early seventeenth century. She was destined to live in difficult and turbulent times. At the time, the coastal regions of Vietnam, including Ly Son Island, were allegedly being harassed by Chinese pirates, who plundered the villages, raped the women, and killed the villagers. Lady Jambose, only sixteen years old at the time, was one of the victims of these invasions.

In his oral story, Anh kept silent about her problematic nature as a ghost and, instead, referred to her as a filial daughter. "She came to the shore as she was looking for her father whom she had tried to warn of the approaching enemy. Surrounded by Chinese pirates she chose death to maintain her virginity and threw herself into the sea." Thus, in a critical moment she did not give up long-standing values, the most important components to filial piety such as care, obedience, and moral vigilance. In his study on popular religion, Taylor (2004, p. 252) notes that many tales about female spirits in Vietnam describe them as loyal daughters and as virgins who commit suicide when raped, resist marriage when obliged to marry a stranger, and remain faithful to their parents or country even after their tragic death. Taylor points out that the undefined nature of these women allowed them to be venerated as "spiritual protectors of the sovereign or bearers of the 'national essence"' (p. 209). In 
scholarly discourse on culture these female spirits are regarded as maintaining and representing the core values of the Vietnamese nation (p. 252). Thus, heroism was an important element of Anh's narratives. He demonstrated that by choosing death, Lady Jambose not only displayed the enduring virtues of a Vietnamese woman, such as chastity and purity, but also became an "indomitable heroine" (anh hung bat khuat) having "consciousness of protecting a dear island" (y thuc bao ve hon dao yeu quy).

The praise of female heroism is not exceptional in Vietnam. The national heroines - the Trung sisters, who fought against the Chinese - were also introduced as defenders of the "sacred land" of Vietnam in post-colonial narratives. Their bravery and "indomitable spirit" passing from one generation to the next to provide, according to socialist interpretation, an inspiration for Vietnamese women to revolt against the enemy (Pelley 2002, p. 181). In Anh's story, Lady Jambose also serves as a moral example for following generations. Furthermore, in his narrative, Anh eloquently combined the supernatural and real and used notions about violent death to show how his ancestress — the young virgin girl — proved herself an efficacious and responsive spirit during the Vietnam War, when her grave served as a hiding place for stolen weapons. In this sense, she gave her protection to the communist guerrillas. He also referred to Ly Son in the present and to local solidarity by indicating her "merit with her hamlet" when she supported her fellows during the boat festival competition, which was recreated on the island by the Quang Ngai Office of Culture in 2004. Thereupon the supernatural events in the story follow: She died on the fifteenth day of the fifth lunar month of 1645 . The family and villagers learned about her tragic suicide through spirit possession rituals (len dong). She appeared sitting in the lotus position similar to Bodhisattva Quan Ying (Quan Am).

Between 2002 and 2006, a number of articles about Lady Jambose, the Hoang Sa soldier, Pham Huu Nhat, and about the lineage itself appeared in local newspapers and magazines. Moreover, the Da Nang television produced several short films about the Pham lineage's 
family rituals. A large campaign promoting the Pham ancestors in the local press and television would not have been possible without the diplomatic skills, eloquence, and good connections of the fifty-eightyear-old Anh (in 2007). Although he was neither head of his lineage nor in charge of the fulfilment of ritual obligations in the ancestral hall, he took on the role of lineage spokesman. His revolutionary past helped him win the support of local officials and well-known public figures, such as the late historian Tran Quoc Vuong among others.

Anh told me that among the members of his lineage were not only those who sacrificed their lives in the recent time of the French and American wars but also in the remote past. He had collected all the available materials about his ancestors, including the annals, newspaper cuttings, photographs, and letters and petitions of famous professors and local authorities of the district and of the province who supported his effort to achieve government recognition. Additionally, the bulky collection titled "The dossier of historical sites of the Pham lineage" included entries of those who have visited him in recent years. Anh also asked me to make an entry in his visitors' book. As a keepsake of my visit a photo was taken and added to his document collection. Unintentionally, I was admitted as a foreign researcher who noticed the "meritorious past" of his family. In his detailed dossier, later given to me as a copy, I could read:

Generations of the Pham lineage and of the people of Ly Son are all the more pervaded by the significance of history; history is a witness of the era, a candle wick of the truth. The vital power of remembrance enlightens people's lives with the memory and awareness of the past.

In the letters and applications for government recognition of Lady Jambose's temple as a historical site submitted by the lineage to the local authorities and to the chairman of Vietnam's Association of Historians in Hanoi, she is, above all, cited as a "virtuous example" ( co dao duc), "showing filial piety" (co hieu), a "symbol of unifying patriotism" (bieu tuong cua thuong yeu nuoc doan ket), and "having merit with the nation" (co cong voi nuoc). One of Anh's main efforts was to show that members of his family cultivated "a national 
character" and patriotic traditions for generations. The other aim was to demonstrate the historical value of the temple where his female ancestor was worshipped. According to his story, the place was converted from a small shrine into a proper temple by the members of the Pham lineage and some villagers in 1897 . He believed that the temple, more than a hundred years old, deserved the rank of historical heritage site. Anh, with the assistance of local authorities, turned for help to a well-known historian, Tran Quoc Vuong, who expressed his support in writing petitions and even took part in the celebration of the $359^{\text {th }}$ anniversary of the death of Lady Jambose, in 2004 .

However, since 2007, the interest of local officials and scholars has weakened. Although there was no contestation concerning Pham Huu Nhat, they gradually withdrew their support of Lady Jambose as a local heroine and her temple as a commemorative site when hesitations and uncertainty appeared regarding Anh's documentation. From the night of the fifteenth to the sixteenth day of the fifth lunar month in 2007, I was invited to take part in the anniversary celebration of her death (gio ba), and I found it to be much more modest than the celebration three years previously, about which I had heard. There were no guests from the province, and I was warmly welcomed as a foreign researcher by the Pham kin group. As I talked with the family members, I discovered that they have different, sometimes contrary versions of the story. Whereas some of them claimed she died during her encounter with Chinese pirates, others argued that she simply drowned in the sea while collecting suffocated fish or algae.

Anh's efforts and the great interest in his family on the part of local agents, intellectuals, journalists, and even television in previous years were seen differently by the villagers. Some of them felt disappointed. Phuc, for example, believed that the shrine located in his yard also deserved to receive governmental recognition as a historical site. The temple was, as in the case of Lady Jambose, devoted to the spirit of a woman who died a violent death. He tried to convince me that the woman was from the royal family, and he asked if I could intercede 
for him with the Provincial Culture Office (So Van Hoa) in Quang Ngai. He lamented that all the relevant annals had somehow been lost, and he thought that I could authenticate his claims. Others, like the Vo lineage and their kin, one of whom was working as an official in Quang Ngai, were sceptical about the accounts of the Pham lineage. When I asked why they were so suspicious they gave an enigmatic reply that there appeared to be strong doubts about the accuracy and authenticity of the Pham's family annals with respect to Lady Jambose, and that even local authorities had to revise their knowledge on that matter.

The villagers who considered Lady Jambose as Pham's ancestress rather than a local heroine denied that they went to her shrine and prayed. The villagers also questioned that Lady Jambose lived at the beginning of the seventeenth century, even if there was no doubt among them that she had indeed existed. They claimed that their very old grandparents remembered her from the time they were children. One member of the Vo lineage doubted whether Chinese pirates operated along the South China Sea coast in 1645 - the year of the supposed death of Lady Jambose. To confirm his doubts, he took me to the head of the Vo lineage, who showed me their family annals in which the first mention of pirates on the island dated from 1789 - 144 years later than the Pham documents suggested. ${ }^{7}$ The document was translated from Sino-Vietnamese to Vietnamese and authorized by the Institute of Han-Nom in Hanoi. The Vo members gave me the annals and pointed out the paragraph where I read:

Until the sixth day of the tenth month of the Ky Dau year (1789), the year when fifteen vessels of Chinese pirates plundered this quarter, the $c u$ (old man) kept all copies of acts. Although all copies of acts were soaked and ragged, the $c u$ even so brought and stored them ...

They refuted Anh's version about Lady Jambose's reputed death at the hands of the Chinese, claiming, rather, her accidental death at sea when she was collecting algae. In their eyes, she was just a ghostly spirit of a young and childless girl, who might pose a threat to the luck of descendants if she was not worshipped, and not a heroine. 
Moreover, they believed that their own forms of proof constitute the only valid history which could challenge Anh's narratives and annals.

\section{Conclusion}

In the end, the question is not whether Anh's narratives are truthful, but what his narratives say about the past as well as about the present, and how the past is remembered, preserved, and reconstructed in the people's memory. As we have seen, the relation between the official notions of the government and the people's views is complex and does not imply separation of the two domains. They are closely interconnected; the people respond to the state political ideology which, at the same time, helps them to understand and reconstruct their own memory.

While this paper is a study of commemoration and the politics of historical narratives, it also seeks to illustrate that the state notions do not simply clash with the people's view, but rather provoke reconstruction of their memory in preferable terms. Local officials often play a crucial role in the course of "historical production" as they are members of the village and somebody's relatives (Trouillot 1995 , p. 28). Moreover, despite their attempts to follow official ideological directives, people have personal preferences and prejudices that affect the process of recovering local memorials. In spring 2009, the Dang lineage, encouraged by provincial authorities, revealed the royal ordinance which its members had preserved for almost two centuries. The document shed new light on the past of Ly Son and on Vietnamese claims to sovereignty over the Paracel and Spratly archipelagos. The local officials became directly engaged in helping the Dang lineage to restore their temple, and providing funds for organizing traditional ceremonies related to Hoang Sa soldiers. ${ }^{8}$ This suggests that villagers too have begun to play a more active role, insofar as they are responding to state narratives. Yet the examples of the Vo and Pham lineages show that re-making the past is not a peaceful process strengthening local or national unity but a process in which conflicts and antagonism come to the fore, as various groups 
and individuals confront one another with variable memories and interpretations of history. However, such confrontation is restricted to specific fields of negotiations, defined by both the state and local initiatives, while other parts of ancient and contemporary history are passed over in silence.

In Ly Son, the multifaceted interaction between modern cultural policies of the state and traditional customs generated a creative array of encounters with the ghosts of those who died as Hoang Sa soldiers or just as young, childless women. Anh adapted his narratives to official currents and gave them their own sense. He accented the continuity with the past, which plays such an important role in the state discourse. But the continuity, he stressed, refers to his lineage, his village, and his island. In the terms of blood relation he shows that the "revolutionary spirit" dates back to the origins of his family and was maintained over generations. His ancestors came to Vietnam's defence whenever the country called them. Moreover, the service to the fatherland was not only a male matter; exceptional courage also characterized the women of Anh's family.

Lady Jambose, who tried to warn her father about the Chinese and, in a critical moment, chose a heroic death, can be interpreted as a metaphor of Vietnam as a victim that always has to defend its sovereignty and independence. In his story, Anh used the Chinese plot, which was analogous to the tensions between China and Vietnam and the Vietnamese struggle to prove their claims over the Paracel and Spratly archipelagos. The Chinese pirates symbolize China's greedy desires for Vietnamese property. When Anh described his ancestress as an indomitable heroine having a "consciousness of protecting a dear island", he was referring to the centuries-old tradition of resisting foreign invaders.

The written sources, such as family records and memorials, took a central place in Anh's argument and his struggle over memory. To authenticate his various forms of proof and his story, he backed them with the authority of intellectuals who helped define Lady Jambose not as a ghostly spirit but above all as a local heroine. However, his narratives provoked counter-narratives among 
the other kin group, as they had their own "recorded and certified memory" - more convincing than any historians, newspapers, or documentary. Therefore, power struggles between the two lineages represent another dimension to the process of recovering local memories. Both Anh and members of the Vo lineage first sought local and genealogical continuity as they wanted to point out that their family members as well as the Ly Son people, though spatially distanced from the mainland, had always contributed to the defence of the nation. National continuity becomes meaningful for them only when incorporated with their local concerns.

On the one hand, the earlier support and the later self-restraint of local officials in including Lady Jambose and her temple in the commemorative project of the Hoang Sa navy shows that the central state, which faces international and local negotiations, tries to control and shape the commemorations as well as to keep them small. These commemorations underline the connection of the modern state with the glorious rulers, with the history of "resistance", and with the struggle of Vietnam's sovereignty and autonomy rather than their continuity with the lineage, village, or the island. The state, aware of the social power of commemorative rituals, did not allow these anniversaries for the Hoang $\mathrm{Sa}$ and Truong Sa soldiers to become a national celebration. On the other hand, local agents have an influence on the state project. Following both the official political line and their own preferences, they deliberately select oral stories, issue articles, hold conferences, and assign spaces that, taken together, recover and reconstruct the remote past in a desirable way (see Endres 2002). The state commemorations are supposed to collectively venerate those whose bodies were dispersed in the Eastern Sea (Bien Dong), whose names sank into oblivion while their bravery and heroism are still worth remembering. However, as we have seen, for those who live in the present this is not enough. They want that the evoked ghostly spirits become the flesh and blood of their kin and have their names carved into stone forever. 


\section{NOTES}

This paper was originally presented at the international conference on Religion in Southeast Asian Politics: Resistance, Negotiation and Transcendence, Institute of Southeast Asian Studies, Singapore, 11-12 December 2008. The author wishes to thanks Nathan Light for his help in developing this article in its early stage. She extends her thanks to Markus Schlecker for his helpful comments at the time. The author is particularly indebted to Pascal Bourdeaux and Kirsten Endres for reading a later version; this paper benefited considerably from their suggestions.

The research for this article was made possible thanks to financial support from the Max Planck Institute for Social Anthropology in Halle, Germany, where Edyta Roszko is a Ph.D. candidate. The author would like to record her special thanks to Andrew Hardy and Nguyen Tien Dong, whose assistance and expertise in the field and excellent relations with the provincial officials was invaluable for the project.

1. Anh is a pseudonym, as are the names of all individuals, with the exception of the names of the lineages and historical and public figures.

2. According to Nguyen Dong Vu $(2001 ; 2002)$ the Hoang Sa navy was established by the Nguyen lords at the end of the sixteenth century or the beginning of the seventeenth century. From the seventeenth century through the eighteenth and the nineteenth centuries the Nguyen dynasty continued to carry out Hoang Sa activities.

3. For a discussion of historical materials with reference to the Hoang Sa and Truong Sa flotillas see Nguyen Nha (1975).

4. Dian Murray (in Hoyt 1994, p. 21) points out that the "concept of sovereignty as delimitating legitimate (legal) authority around political space and of state territoriality as rule over space defined by geometric grids were not functions of the Confucian world view. Within the Confucian order, sovereignty was defined more concretely in terms of human residence and social organization. Places without human occupation were regarded as frontiers beyond civilization and, hence, of little concern. With oceanic sovereignty or the extension of state authority over uninhabited stretches of the sea playing little part in Confucian political theory, the offshore islands, empty and uninhabited, were never meaningfully incorporated into the empires of either China or Vietnam"; Murray (1987, p. 21) also notes that in the nineteenth century there was still disagreement between cartographers about the exact location of the Paracel and Spratly islands, which were considered as little more than a hazard to surface navigation. 
5. See Ministry of Foreign Affairs Socialist Republic of Vietnam (1981).

6. At the beginning of the seventeenth century, the first migrants came from the mainland villages, An Vinh and An Hai near Sa Ky port of Quang Ngai province, divided land between them, founded new villages and struggled to make a living off the sandy soil. According to the Pham lineage, this happened in 1609. For more details about the location of the two villages see Ngo Duc Tho and Nguyen Van Nguyen (2006).

7. We have too little evidence to verify the Pham lineage annals or to prove the Vo lineage doubts. However, Murray (1987) confirms that piracy emerged in the South China Sea only in the late eighteenth century. In 1773, the Tay Son Rebellion established its rule in Quang Nam, Quang Ngai, and Binh Dinh provinces and recruited Chinese pirates, who supported the Vietnamese rebels. At that time they might have operated on the offshore islands of this area.

8. Viet Nam Net Bridge, 19 April and 6 May 2009.

\section{REFERENCES}

Anagnost, Ann S. "The Politics of Ritual Displacement". In Asian Visions of Authority: Religion and the Modern States of East and Southeast Asia, edited by Charles F. Keyes, Laurel Kendall, and Helen Hardacre. Honolulu: University of Hawai'i Press, 1994.

Boudarel, Georges. "L'insertion du pouvoir central dans les cultes villageois au Vietnam: esquisse des problemes a partir des ecrits de Ngo Tat To". In Cultes populaires et societetes asiatiques: Appareils cultuels et appareils de pouvoir, edited by Alan Forest, Yoshiaki Ishizawa, and Leon Vandermeersch. Tokyo: Centre National de la Recherche Scientifique, l'Universite Paris, l'Institute of Asian Cultures, l'Universte Sophia, 1991.

Connerton, Paul. How Societies Remember. Cambridge: Cambridge University Press, 1999.

Dang Nghiem Van. Ethnological and Religious Problems in Vietnam. Hanoi: Social Sciences Publishing House, 1998.

DiGregorio and Salemink. "Living with the Dead: The Politics of Ritual and Remembrance in Contemporary Vietnam". Journal of Southeast Asian Studies 38, no. 3 (October 2007).

DiGregorio, Michael. "Things held in Common: Memory, Space and the Reconstitution of Community Life". Journal of Southeast Asian Studies 38, no. 3 (October 2007).

Do, Thien. Vietnamese Supernaturalism: Views from the Southern Region. London: RoutledgeCurzon, 2003. 
Endres, Kirsten. "Local Dynamics of Renegotiating Ritual Space in Northern Vietnam: The Case of the Dinh". SOJOURN: Journal of Social Issues in Southeast Asia 16, no. 1 (2001).

- "Beautiful Customs, Worthy Traditions: Changing State Discourse on the Role of Vietnamese Culture". Internationales Asienforum 33, nos. 3-4 (2002).

Evans, Grant, The Politics of Ritual and Remembrance: Laos Since 1975. Honolulu: University of Hawai'i Press, 1998.

Han Nguyen, "Nhung su lieu chu Han minh chung chu quyen cua Viet Nam tren Quan Dao Hoang Sa va Truong Sa qua nhieu the ky [Some historical documents written in Chinese characters prove sovereignty of Vietnam over the Paracel and Spratly Archipelagos over many centuries]". Su Dia 29, nos. 1-3 (1975).

Ho Tai, Hue Tam. "Monumental Ambiguity: The State Commemoration of Ho Chi Minh". In Essays into Vietnamese Past, edited by K.W. Taylor. Ithaca: Cornell University, 1995.

- eds. The Country of Memory: Remaking the Past in Late Socialist Vietnam. Berkley: University of California Press, 2001.

Ho Tai, Hue Tam and Le Hong Ly. "The Revenge of the Object: Villagers and Ethnographers in Dong Ky Village”. Asian Ethnology 67, no. 2 (2008).

Hoyt, Mark A. "Sino-Vietnamese Interests Collide in the South China Sea: A Case Study of the Disputed Paracel and Spratly Archipelagos". MA dissertation, University of Hawai $i$, 1994.

Kendall, Laurel. "The Cultural Politics of 'Superstition' in the Korean Shaman World: Modernity Constructs its Other". In Healing Powers and Modernity: Traditional Medicine, Shamanism and Science in Asian Societies, edited by Linda H. Connor and Geoffrey Samuel. Westport, CT: Greenwood Publishing, 2001.

Kertzer, David. Ritual, Politics and Power. New Haven, CT: Yale University Press, 1988.

Keyes, Charles F. "National Heroine or Local Spirit? The Struggle over Memory in the Case of Thao Suranari of Nakhon Ratchasima". In Cultural Crisis and Social Memory: Modernity and Identity in Thailand and Laos, edited by Tanabe Shigeharu and Charles F. Keyes. London: RoutledgeCurzon, 2002.

Kwon, Heonik. After the Massacre: Commemoration and Consolation in Ha My and My Lai. Berkley: University of California Press, 2006.

- Ghost of War in Vietnam. Cambridge: Cambridge University Press, 2009.

Lang Ho. "Hoang Sa va Truong Sa, Lanh tho Viet Nam [The Paracel and Spratly - Vietnamese territory]”. Su Dia 29, nos. 1-3 (1975). 
Le Quy Don. Phu Bien Tap Luc [A compilation of the miscellaneous records when the southern border was pacified], vol. 1, Saigon: Phu Quoc Vu Khanh Dac Trach Van Hoa, 1972.

Luong Van Hy. Revolution in the Village: Tradition and Transformation in North Vietnam, 1925-1988. Honolulu: University of Hawai'i Press, 1992.

Malarney, Shaun Kingsley. “'The Fatherland Remembers Your Sacrifice': Commemorating War Dead in North Vietnam". In The Country of Memory: Remaking the Past in Late Socialist Vietnam, edited by Hue Tam Ho Tai: Berkley: University of California Press, 2001.

. Culture, Ritual and Revolution in Vietnam. London: RoutledgeCurzon, 2002.

- "Festivals and the Dynamics of the Exceptional Dead in Northern Vietnam". Journal of Southeast Asian Studies 38, no. 8 (October 2007).

Ministry of Foreign Affairs, Socialist Republic of Vietnam. "The Hoang Sa and Truong Sa Archipelagos Vietnamese Territories" < http://www.megauplpad. com/?d=AK3FNVNN> (accessed 21 May 2009).

Murray, Dian H. Pirates of the South China Sea 1790-1810. Stanford: Stanford University Press, 1987.

Ngo Duc Thinh. Tin nguong va van hoa tin nguong o Viet Nam [Beliefs and religious culture in Vietnam]. Ha Noi: Nha xuat ban Khoa hoc xa hoi, 2001.

Ngo Duc Tho and Nguyen Van Nguyen. Quoc su quan trieu Nguyen: Dong khanh dia du chi, tinh Quang Ngai [National history of the Nguyen dynasty: Dong Khanh's geography of the country, Quang Ngai Province]. Quang Ngai: Vien nghien cuu Han Nom [Institute of Han Nom Language], 2006.

Nguyen Dang Vu. “Tu viec xac lap nguon goc doi Hoang Sa nghi ve viec ton tao cac di tich lien quan tren dat Quang Ngai [On the establishment of the origin of Hoang Sa army: Deliberations on the preservation of various historical sites connected with the Quang Ngai area]". Tap Chi Van hoa nghe thuat 11 (2001).

-. "Le khao le the linh Hoang Sa [Customary ceremony of replacing a former soldier with a new recruit]". Tap Chi Nghien Cuu Dong Nam A 5 (2002).

Nguyen Nha. "Dac Khao ve Hoang Sa va Truong Sa" [Solid research on the Paracel and Spratly]. Su Dia 29, nos. 1-3 (1975).

Nguyen Quang Ngoc and Vu Van Quan. "Tu lieu ve nguon goc, chuc nang va hoat dong cua doi Hoang Sa" [Documents on the origin, tasks and activities of the Paracel team]. Tap Chi Khoa hoc Dai Hoc Quoc gia Ha Noi 14, no. 3 (1998).

Pelley, Patricia M. Postcolonial Vietnam: New Histories of the National Past. Durham: Duke University Press, 2002.

Pham Quynh Phuong. Hero and Deity: Tran Hung Dao and the Resurgence of 
Popular Religion in Vietnam. Bangkok: Mekong Press, 2009.

Poon, Shuk-Wah. "Refashioning Festivals in Republican Guangzhou". Modern China 30, no. 2 (April 2004).

-. "Religion, Modernity, and Urban Space: The City God Temple in Republican Guangzhou". Modern China 34, no. 2 (April 2008).

Siu, Helen F. "Recycling Rituals: Politics and Popular Culture in Contemporary Rural China”. In Unofficial China: Popular Culture and Thought in the People's Republic, edited by Perry Link, Richard Madsen, and Paul G. Pickowicz. Boulder: Westview Press, 1989.

Son Hong Duc. "Thu khao sat ve quan dao Hoang Sa” [An attempt to investigate the Paracel Archipelago]. Su Dia 29, nos. 1-3 (1975).

Taylor, Philip. Goddess on the Rise: Pilgrimage and Popular Religion in Vietnam. Honolulu: University of Hawai'i Press, 2004.

Tran The Duc and Nguyen Van Huong. "Thu muc chu giai ve Hoang Sa" [An annotated bibliography on Paracel]. Su Dia 29, nos. 1-3 (1975).

Trouillot, Michel Rolph. Silencing the Past: Power and the Production of History. Boston: Beacon Press, 1995.

UBND Tinh Quang Ngai and So van Hoa Thong Tin, Bao cao cua So VHTT Quang Ngai ve viec xay dung ton tao khu di tich Hoang Sa — Truong Sa tren huyen dao Ly Son [Report of the Office of Culture and Information of Quang Ngai on reconstructing and embellishment of a zone of the Paracel - Spratly on Ly Son Island]. Quang Ngai, 2001.

Viet Nam Net Bridge, "Islander Honour the Sacrifice of Ancient Sailors Lost at Sea" <http://english.vietnamnet.vn/reports/2009/04/842823> (accessed 20 April 2009).

- "Royal Ordinance on Hoang Sa Proposed for National Recognition" <http://english.vietnamnet.vn/politics/2009/05/846025>, accessed 24 June 2009.

Watson, James L. "Standardising the God". In Popular Culture in Late Imperial China, edited by David Johnson, Andrew J. Nathan, and Evelyn S. Rawski. Taipei: SMC Publishing, 1985.

Wolf, Arthur P. "Gods, Ghost, and Ancestors". In Religion and Ritual in Chinese Society, edited by Arthur P. Wolf. Stanford: Stanford University, 1974.

Wolters, Oliver W. Two Essays on Dai-Viet in the Fourteenth Century. New Haven, CT: Council of Southeast Asian Studies, Yale Centre for International and Area Studies, 1988.

Yang, C.K. Religion in Chinese Society. Berkeley: University of California Press, 1967.

Edyta Roszko is a Ph.D. candidate at the Max Planck Institute, Leipzig. 